\title{
Addition of glycerol to lactating cow diets stimulates dry matter intake and milk protein yield to a greater extent than addition of corn grain
}

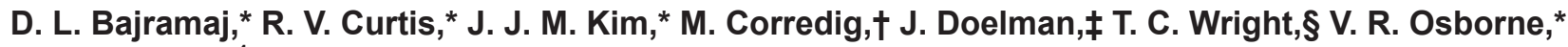 \\ and J. P. Cant*1 \\ *Department of Animal Biosciences, and \\ †Department of Food Science, University of Guelph, Ontario, N1G 2W1 Canada \\ $\ddagger$ Nutreco Canada Agresearch, Guelph, Ontario, N1G 4T2 Canada \\ §Ontario Ministry of Agriculture, Food and Rural Affairs, Guelph, Ontario, N1G 4Y2 Canada
}

\section{ABSTRACT}

The objective of this study was to determine if the addition of glycerol to the diet of dairy cows would stimulate milk protein yield in the same manner as the addition of corn grain. Twelve multiparous lactating dairy cows at $81 \pm 5 \mathrm{~d}$ in milk were subjected to 3 dietary treatments in a replicated $3 \times 3$ Latin square design for 28 -d periods. The diets were a $70 \%$ forage diet considered the basal diet, the basal diet with $19 \%$ ground and high-moisture corn replacing forages, and the basal diet with $15 \%$ refined glycerol and $4 \%$ added protein supplements to be isocaloric and isonitrogenous with the corn diet. Cows were milked twice a day and samples were collected on the last $7 \mathrm{~d}$ of each period for compositional analysis. Within each period, blood samples were collected on d 26 and 27, and mammary tissue was collected by biopsy on d 28 for Western blot analysis. Dry matter intake increased from $23.7 \mathrm{~kg} / \mathrm{d}$ on the basal diet to $25.8 \mathrm{~kg} / \mathrm{d}$ on the corn diet and 27.2 $\mathrm{kg} / \mathrm{d}$ on the glycerol diet. Dry matter intake tended to be higher with glycerol than corn. Milk production increased from $39.2 \mathrm{~kg} / \mathrm{d}$ on the basal diet to $43.8 \mathrm{~kg} / \mathrm{d}$ on the corn diet and $44.2 \mathrm{~kg} / \mathrm{d}$ on the glycerol diet. However, milk yield did not differ between corn and glycerol diets. Milk lactose yields were higher on the corn and glycerol diets than the basal diet. Milk fat yield significantly decreased on the glycerol diet compared with the basal diet and tended to decrease in comparison with the corn diet. Mean milk fat globule size was reduced by glycerol feeding. Milk protein yield increased $197 \mathrm{~g} / \mathrm{d}$ with addition of corn to the basal diet and $263 \mathrm{~g} / \mathrm{d}$ with addition of glycerol, and the glycerol effect was larger than the corn effect. The dietary treatments had no effects on plasma glucose concentra-

Received November 30, 2016.

Accepted April 22, 2017.

${ }^{1}$ Corresponding author: jcant@uoguelph.ca tion, but plasma acetate levels decreased $27 \%$ on the glycerol diet. Amino acid concentrations were not affected by dietary treatments, except for branched-chain amino acids, which decreased $22 \%$ on the glycerol diet compared with the corn diet. The decreases in plasma acetate and branched-chain amino acid concentrations with glycerol and the larger effects of glycerol than corn on milk protein and fat yields suggest that glycerol is more glucogenic for cows than corn grain.

Key words: glycerol, milk synthesis, mammary, milk fat globule

\section{INTRODUCTION}

Milk protein yield in dairy cattle is stimulated by an elevated postruminal supply of glucose or propionate (Rulquin et al., 2004; Raggio et al., 2006), as well as higher inclusion levels of dietary grain (Macleod et al., 1983). The mechanism responsible for this stimulation of milk protein yield is unclear. The effect of grain feeding may be explained in part by an increase in microbial protein outflow from the rumen (Rode et al., 1985), leading to greater absorption of EAA, but microbial outflow is not always affected (Klusmeyer et al., 1991; Cameron et al., 1991). Insulin, which is released during glucose infusion and grain feeding (Macleod et al., 1983; Rulquin et al., 2004), stimulates milk protein yield (Mackle et al., 2000; Bequette et al., 2001), presumably through the insulin signaling cascade inside mammary epithelial cells. Essential amino acids and insulin are both activators of the mechanistic target of rapamycin complex 1 (mTORC1) in mammary epithelial cells (Burgos et al., 2010; Appuhamy et al., 2011) that may be responsible for nutritional stimulation of milk protein synthesis. Glucose, glucose precursors, and grains also depress milk fat production (Balch et al., 1955; Sutton, 1989; Lemosquet et al., 1997; Hurtaud et al., 1998; Rigout et al., 2002), partly through conjugated linoleic acid formation in the rumen (Loor and Herbein, 1998; Bauman et al., 2008) and partly through insulin- 
mediated inhibition of mammary lipoprotein lipase activity (Mackle et al., 2000; Cant et al., 2002).

Glycerol is a glucogenic precursor (Cori and Shine, 1935 ) that may become available as a feed ingredient for cattle as a co-product of biodiesel manufacture. As a glucogenic feedstuff, glycerol has several features in common with corn grain. Degradation of glycerol in the rumen increases the proportions of propionate and butyrate at the expense of acetate (Rémond et al., 1993; Wang et al., 2009a). Ruminal degradation of corn grain also increases propionate and butyrate at the expense of acetate (Hess et al., 1996; Valadares et al., 1999). In addition to VFA production, 30 to $50 \%$ of the starch in corn grain is digested to glucose in the small intestine (Rémond et al., 2004; Taylor and Allen, 2005), a portion of which may enter the bloodstream. In a similar fashion, approximately half of the glycerol consumed is absorbed across the rumen wall into blood, where it becomes available for hepatic gluconeogenesis (Rémond et al., 1993). Because of these similarities in fermentation pattern and glucogenicity, glycerol may be comparable to glucose or corn grain in its effect on milk component yields.

Whether addition of glycerol to the diet stimulates milk protein yield the way addition of corn grain does has not been evaluated to our knowledge. In several experiments, isocaloric inclusions of refined glycerol up to $15 \%$ of diet DM have not affected intake, rumen microbial protein yield, or milk protein yield (Khalili et al., 1997; Carvalho et al., 2011; Kass et al., 2012). Isocaloric substitution of $8 \%$ crude glycerol for corn grain increased milk protein yield in an experiment by Wilbert et al. (2013). Hypercaloric additions of glycerol to the diet, instead of isocaloric substitutions, have been made at much smaller doses and in the context of preventing metabolic disorders associated with the transition into lactation (DeFrain et al., 2004; Chung et al., 2007; Wang et al., 2009b). These additions have not resulted in changes in DM intakes or milk component yields. When glycerol was included at $20 \mathrm{~g} / \mathrm{L}$ in the drinking water of transition cows, for a glycerol intake equal to $1.3 \mathrm{~kg} / \mathrm{d}$ or $10 \%$ of DMI, ad libitum consumption of the diet decreased so that $\mathrm{NE}_{\mathrm{L}}$ intake was not affected and milk component yields remained unchanged (Osborne et al., 2009). Isocaloric replacement of concentrate with glycerol depressed milk fat yield in one experiment (Vallance and McClymont, 1959) but not in others (Khalili et al., 1997; Carvalho et al., 2011; Kass et al., 2012). Effects on milk yield and composition may be difficult to detect with statistical significance when glycerol replaces grain isocalorically, but they may be easier to detect when glycerol is added hypercalorically to a diet. For use as a major feed in- gredient in milking cow rations throughout lactation, it would be useful to know if addition of glycerol can stimulate daily milk yield, and if it stimulates milk protein and depresses milk fat production in the manner of a corn grain addition. Our hypothesis was that the fermentability and glucogenicity of glycerol would lead to a milk protein stimulation and milk fat depression when added to increase the energy density of lactating cow diets. Our objective was to compare the hypercaloric effects of corn and glycerol on milk production and composition and mammary mTORC1 signaling.

\section{MATERIALS AND METHODS}

\section{Animals, Housing, and Diets}

The Animal Care Committee at the University of Guelph approved all experimental procedures in this study. Twelve multiparous, lactating Holstein cows $(674 \pm 66 \mathrm{~kg} \mathrm{BW} ; 81 \pm 5 \mathrm{DIM})$ were housed in a tie-stall barn and given free access to feed and water throughout the study. Cows were assigned to 3 dietary treatments (Table 1 ) in a replicated $3 \times 3$ Latin square design of three 28 -d periods. The 3 diets were a $70 \%$ forage basal TMR (BAS), the basal TMR with $19 \%$ of the forages substituted for corn grain (CG), and the basal TMR with $19 \%$ of the forages substituted for refined glycerol from a soybean oil source $(99.7 \%$ glycerol; Palmera G997U, KLK Oleo, Selangor, Malaysia) plus protein supplements (GLYC). The CG and GLYC diets were formulated to be isocaloric and isonitrogenous and to contain $30 \%$ NDF, compared with $38 \%$ NDF for the BAS diet.

\section{Sample Collection and Analysis}

The amounts of feed offered and refused were recorded daily for each individual cow to estimate feed intakes. Orts were sampled from each cow and pooled on the last week of each period. Samples of each diet were collected daily, pooled by period, and submitted for nutrient composition analyses by wet chemistry at a commercial laboratory (Agri-Food Labs, Guelph, ON, Canada). Dry matter contents of feed and orts samples were determined using a forced-air oven at $60^{\circ} \mathrm{C}$ for 24 h.

Cows were milked at 0500 and $1530 \mathrm{~h}$ daily, and milk yields were recorded. Milk samples were collected from each milking during the last $7 \mathrm{~d}$ of each period and submitted for compositional analysis by infrared spectroscopy (Laboratory Services Division, University of Guelph, ON, Canada). Fresh milk samples from d 23, 25 , and 27 of each period were also subjected to analy- 
Table 1. Ingredient and chemical composition (\% of DM unless otherwise noted; mean $\pm \mathrm{SD} ; \mathrm{n}=3$ ) of experimental diets

\begin{tabular}{|c|c|c|c|}
\hline \multirow[b]{2}{*}{ Item } & \multicolumn{3}{|c|}{ Treatment $^{1}$} \\
\hline & BAS & $\mathrm{CG}$ & GLYC \\
\hline \multicolumn{4}{|l|}{ Ingredient composition } \\
\hline Straw & 7.3 & 5.0 & 5.0 \\
\hline Alfalfa silage & 31.2 & 21.6 & 21.6 \\
\hline Corn silage & 31.2 & 21.6 & 21.6 \\
\hline Corn, high-moisture & 14.3 & 9.9 & 9.9 \\
\hline Corn, ground & 0 & 23.4 & 4.3 \\
\hline Glycerol & 0 & 0 & 15.3 \\
\hline Soybean meal & 6.8 & 8.0 & 9.8 \\
\hline Canola & 6.8 & 8.0 & 9.8 \\
\hline Corn gluten meal & 0.8 & 0 & 0.4 \\
\hline Vitamin/mineral premix & 1.8 & 2.4 & 2.2 \\
\hline \multicolumn{4}{|l|}{ Chemical composition } \\
\hline $\mathrm{CP}$ & $17.1 \pm 1.6$ & $17.4 \pm 0.4$ & $19.0 \pm 0.9$ \\
\hline Soluble $\mathrm{CP}, \%$ of $\mathrm{CP}$ & $44.3 \pm 3.8$ & $35.2 \pm 9.5$ & $30.6 \pm 10.2$ \\
\hline NDICP, $2 \%$ of $\mathrm{CP}$ & $29.6 \pm 4.5$ & $27.5 \pm 1.2$ & $39.3 \pm 1.5$ \\
\hline $\mathrm{ADICP},{ }^{2} \%$ of $\mathrm{CP}$ & $10.2 \pm 3.9$ & $7.6 \pm 1.4$ & $9.2 \pm 0.8$ \\
\hline $\mathrm{NDF}$ & $37.9 \pm 1.9$ & $30.7 \pm 2.9$ & $31.6 \pm 2.8$ \\
\hline $\mathrm{ADF}$ & $25.7 \pm 0.2$ & $19.4 \pm 3.0$ & $19.8 \pm 0.8$ \\
\hline Lignin & $4.9 \pm 0.7$ & $3.8 \pm 0.5$ & $4.2 \pm 0.2$ \\
\hline $\mathrm{NFC}^{3}$ & $40.2 \pm 1.0$ & $46.7 \pm 2.6$ & $46.5 \pm 2.3$ \\
\hline Starch, $\%$ of NFC & $35.4 \pm 2.5$ & $51.1 \pm 2.8$ & $29.3 \pm 0.7$ \\
\hline Glycerol, ${ }^{4} \%$ of NFC & 0 & 0 & 32.9 \\
\hline Ether extract & $2.6 \pm 0.2$ & $3.0 \pm 0.2$ & $3.3 \pm 0.0$ \\
\hline Ash, & $7.2 \pm 0.4$ & $7.0 \pm 0.0$ & $7.1 \pm 0.3$ \\
\hline $\mathrm{NE}_{\mathrm{L}},{ }^{3} \mathrm{Mcal} / \mathrm{kg}$ of $\mathrm{DM}$ & $1.55 \pm 0.02$ & $1.66 \pm 0.05$ & $1.67 \pm 0.03$ \\
\hline \multicolumn{4}{|c|}{$\begin{array}{l}{ }^{1} \mathrm{BAS}=70 \% \text { forage basal TMR; CG = basal TMR with } 19 \% \text { of the forages substit } \\
=\text { basal TMR with } 19 \% \text { of the forages substituted for refined glycerol from a soyb } \\
\text { supplements. } \\
{ }^{2} \mathrm{NDICP}=\text { neutral detergent insoluble } \mathrm{CP} \text {; ADICP = acid detergent insoluble CP. } \\
{ }^{3} \text { Calculated according to NRC }(2001) .\end{array}$} \\
\hline
\end{tabular}

sis of fat globule size distribution by integrated light scattering (Mastersizer S, Malvern Instruments, Southborough, MA) according to Roesch et al. (2004). Average volume-weighted diameter $\left(\mathbf{d}_{4,3}\right)$ was calculated as $\Sigma \mathrm{N}_{\mathrm{i}} \mathrm{d}_{\mathrm{i}}^{4} / \Sigma \mathrm{N}_{\mathrm{i}} \mathrm{d}_{\mathrm{i}}^{3}$, and average surface-weighted diameter $\left(\mathbf{d}_{3,2}\right)$ was calculated as $\Sigma \mathrm{N}_{\mathrm{i}} \mathrm{d}_{\mathrm{i}}^{3} / \Sigma \mathrm{N}_{\mathrm{i}} \mathrm{d}_{\mathrm{i}}^{2}$, where $\mathrm{N}_{\mathrm{i}}$ is the number of fat globules with diameter $\mathrm{d}_{\mathrm{i}}$. Specific area of fat globules was calculated as $6 /\left(0.92 \times \mathrm{d}_{3,2}\right)$, and fat globule membrane yields were calculated according to Couvreur et al. (2007) as specific area $\left(\mathrm{m}^{2} / \mathrm{g}\right) \times 10 \mathrm{~nm}$ membrane thickness $\times$ milk fat yield $(\mathrm{g} / \mathrm{d})$.

Energy balance of cows was calculated as $\mathrm{NE}_{\mathrm{L}}$ intake - $\mathrm{NE}_{\mathrm{L}}$ milk - $\mathrm{NE}_{\mathrm{L}}$ maintenance, where $\mathrm{NE}_{\mathrm{L}}$ intake was calculated from observed $\mathrm{DMI}$ and calculated $\mathrm{NE}_{\mathrm{L}}$ content; $\mathrm{NE}_{\mathrm{L}}$ milk was obtained from the regression equation of Tyrrell and Reid (1965) against observed milk fat, protein, and lactose yields; and $\mathrm{NE}_{\mathrm{L}}$ maintenance $=0.08 \mathrm{BW}^{0.75}(\mathrm{NRC}, 2001)$. The $\mathrm{NE}_{\mathrm{L}}$ content of glycerol was assumed to be $2.1 \mathrm{Mcal} / \mathrm{kg}$, based on an average of estimates ranging from 1.9 to $2.3 \mathrm{Mcal} / \mathrm{kg}$ (DeFrain et al., 2004; Wilbert et al., 2013).
Blood samples were collected by tail venipuncture on d 26 and 27 of each period and centrifuged at $2000 \times$ $g$ for $10 \mathrm{~min}$. Plasma was transferred to polypropylene tubes for storage at $-20^{\circ} \mathrm{C}$. Samples were thawed and analyzed by enzyme-linked spectrophotometry for glucose, acetate, BHB, nonesterified fatty acids (NEFA) and triacylglycerol (TAG) as described by Curtis et al. (2014). Plasma AA concentrations were analyzed by UPLC (Waters Corporation, Milford, MA) according to Boogers et al. (2008).

On the last day of each period, following the morning milking, mammary tissue was collected by biopsy from one hindquarter of the 6 cows comprising 2 of the $3 \times 3$ Latin squares. Cows were sedated with 0.5 $\mathrm{mL}$ of xylazine i.v., ketoprofen $(3 \mathrm{mg} / \mathrm{kg}$ of BW) was administered intramuscularly, and $5 \mathrm{~mL}$ of lidocaine was injected subcutaneously at the biopsy site. Tissue was collected aseptically using the device of Farr et al. (1996). Samples were immediately rinsed with saline, snap-frozen in liquid $\mathrm{N}_{2}$, and stored at $-80^{\circ} \mathrm{C}$ for further processing and analysis. 
Approximately $500 \mathrm{mg}$ of mammary tissue were homogenized in $1 \mathrm{~mL}$ of RIPA lysis buffer (1\% Triton $\mathrm{X}-100,0.1 \%$ SDS, $50 \mathrm{~m} M$ Tris- $\mathrm{HCl} \mathrm{pH} 8.0,150$ $\mathrm{m} M \mathrm{NaCl}$, and $0.5 \%$ sodium deoxycholate) containing protease and phosphatase inhibitor cocktail (Thermo Scientific, Nepean, ON), and supernatants were recovered after centrifuging at 13,000 $\times g$ for 15 min at $4^{\circ} \mathrm{C}$. Supernatants were analyzed for DNA concentration with the Qubit dsDNA BR assay using a Qubit 2.0 Fluorometer (Life Technologies Inc., Burlington, ON, Canada), RNA concentration with the Qubit RNA BR assay (Life Technologies Inc.), and protein concentration with the BCA Protein Assay Kit (Pierce, Rockford, IL) using bovine serum albumin as a standard.

Supernatants of mammary samples were subjected to Western blotting as described by Curtis et al. (2014) with modifications. Briefly, samples containing $20 \mu \mathrm{g}$ of protein, along with BLUeye Prestained Protein Ladder (FroggaBio, Toronto, ON, Canada), were separated by $10 \%$ SDS-PAGE and transferred onto polyvinylidene difluoride membranes (Millipore, Mississauga, ON, Canada) before incubation with rabbit monoclonal antibodies against ribosomal $\mathrm{S} 6$ kinase 1 (S6K1; no. ab9366, Abcam, Cambridge, MA), phosphorylated S6K1 (Thr389, no. ab2571, Abcam), eukaryotic initiation factor $2 \alpha$ (eIF $2 \alpha$; no. 9722; Cell Signaling Technology Inc., Danvers, MA), phosphorylated eIF2 $\alpha$ (Ser51, no. 3597, Cell Signaling), eIF4E-binding protein 1 (4EBP1; no. 9452, Cell Signaling Technology Inc.), phosphorylated 4EBP1 (Ser65, no. 9451, Cell Signaling Technology Inc.), protein kinase R-like endoplasmic reticulum kinase (PERK; no. 3192, Cell Signaling Technology Inc.), phosphorylated PERK (Thr980, no. 3179, Cell Signaling Technology Inc.), eIF2B $\varepsilon$ (no. ab32713, Abcam), phosphorylated eIF2B $\varepsilon$ (Ser539, no. ab4775, Abcam), AMP-activated protein kinase a (AMPK $\mathbf{\alpha}$; no. 2603, Cell Signaling Technology Inc.), or phosphorylated AMPKa (Thr172, no. 2535, Cell Signaling Technology Inc.). Appropriate portions of each membrane were also probed for $\beta$-actin (no. ab6276, Abcam), as a loading control. Membranes were then washed, incubated at room temperature for $1 \mathrm{~h}$ with horseradish peroxidase-linked anti-rabbit IgG (no. 7074, Cell Signaling), and developed using enhanced chemiluminescence (Amersham, Arlington Heights, IL). Blot densities in scanned images were determined by ImageLab software (Bio-Rad Laboratories Inc., Mississauga, ON) and normalized to the corresponding $\beta$-actin blot density. Phosphorylation state of each protein was calculated as the ratio of phosphorylated to total protein blot densities.

\section{Statistical Analysis}

Mean performance and plasma metabolite observations during the last week of each period and Western blot results were subjected to ANOVA using PROC MIXED of SAS (SAS Institute Inc., Cary, NC) according to the following model:

$$
\mathrm{Y}_{\mathrm{ijk}}=\mu+\operatorname{cow}_{\mathrm{i}}+\operatorname{Per}_{\mathrm{j}}+\operatorname{Trt}_{\mathrm{k}}+\varepsilon_{\mathrm{ijk}},
$$

where $\mu=$ overall mean, $\mathrm{cow}_{\mathrm{i}}=$ random effect of cow ( $\mathrm{i}=1$ to 12$),$ Per $_{\mathrm{j}}=$ fixed effect of period ( $\mathrm{j}=1$ to 3 ), $\operatorname{Trt}_{\mathrm{k}}=$ fixed effect of treatment ( $\mathrm{k}=1$ to 3$)$, and $\varepsilon_{\mathrm{ijk}}$ $=$ residual error. Least-squares treatment means were separated using the pdiff option of SAS when overall treatment $P<0.10$. Differences were considered significant at $P \leq 0.05$ and tendencies at $0.05<P \leq 0.10$.

\section{RESULTS}

\section{Intake and Lactational Performance}

A difference in DMI was found between the BAS diet compared with CG and GLYC treatments (Table 2). On a DM basis, cows offered CG ate $2.1 \mathrm{~kg} / \mathrm{d}$ more than cows fed the BAS diet $(P<0.01)$, and cows offered GLYC ate $3.5 \mathrm{~kg} / \mathrm{d}$ more than those given the BAS diet $(P<0.01)$. The $1.4 \mathrm{~kg} / \mathrm{d}$ higher DMI on GLYC compared with CG tended to be significant $(P$ $=0.06)$.

Cows that were fed the CG diet produced $4.6 \mathrm{~kg} / \mathrm{d}$ more milk than those on the BAS diet $(P<0.01)$, and cows that were fed GLYC produced $5.0 \mathrm{~kg} / \mathrm{d}$ more $(P<$ 0.01). Milk yield did not differ between GLYC and CG. Daily protein yield increased by $197 \mathrm{~g} / \mathrm{d}(P<0.01)$ and $263 \mathrm{~g} / \mathrm{d}(P<0.01)$ for the CG and GLYC diets, respectively, in comparison with the BAS diet. The protein yield on GLYC was $66 \mathrm{~g} / \mathrm{d}$ higher than on CG ( $P$ $=0.05)$. Milk fat yields were not affected by addition of corn to the BAS diet, but GLYC depressed milk fat yield by $140 \mathrm{~g} / \mathrm{d}(P=0.02)$ compared with BAS and tended to depress milk fat yield by $101 \mathrm{~g} / \mathrm{d}$ compared with CG $(P=0.08)$. Daily lactose yield increased by $283 \mathrm{~g} / \mathrm{d}$ on the CG diet $(P<0.01)$ and $285 \mathrm{~g} / \mathrm{d}$ on the GLYC diet $(P<0.01)$ compared with the BAS diet.

Protein percentage increased by $0.14(P<0.01)$ and $0.25(P<0.01)$ units in milk from cows fed CG and GLYC, respectively, compared with BAS (Table 2). Protein percentage was higher on GLYC than CG $(P$ $=0.04)$. Milk fat percentage decreased by $0.43(P<$ $0.001)$ or $0.69(P<0.001)$ units with addition of $\mathrm{CG}$ or GLYC to the BAS diet and was lower with GLYC 
Table 2. Dry matter intake, milk yield and composition, and $\mathrm{NE}_{\mathrm{L}}$ balance of lactating dairy cattle $(\mathrm{n}=12)$ during the last $7 \mathrm{~d}$ of being fed BAS, CG, and GLYC diets ${ }^{1}$ for $28 \mathrm{~d}$

\begin{tabular}{|c|c|c|c|c|c|}
\hline \multirow[b]{2}{*}{ Item } & \multicolumn{3}{|c|}{ Treatment } & \multirow[b]{2}{*}{ SEM } & \multirow[b]{2}{*}{$P$-value } \\
\hline & BAS & $\mathrm{CG}$ & GLYC & & \\
\hline$\overline{\mathrm{DMI}}, \mathrm{kg} / \mathrm{d}$ & $23.7^{\mathrm{a}}$ & $25.8^{\mathrm{b}}$ & $27.2^{\mathrm{b}}$ & 1.0 & $<0.01$ \\
\hline \multicolumn{6}{|l|}{ Yield } \\
\hline Milk, kg/d & $39.2^{\mathrm{a}}$ & $43.8^{\mathrm{b}}$ & $44.2^{\mathrm{b}}$ & 2.1 & $<0.01$ \\
\hline Protein, g/d & $1,242^{\mathrm{a}}$ & $1,439^{\mathrm{b}}$ & $1,505^{\mathrm{c}}$ & 50 & $<0.01$ \\
\hline Fat, g/d & $1,470^{\mathrm{b}}$ & $1,432^{\mathrm{b}}$ & $1,330^{\mathrm{a}}$ & 66 & 0.05 \\
\hline Lactose, $\mathrm{g} / \mathrm{d}$ & $1,864^{\mathrm{a}}$ & $2,148^{\mathrm{b}}$ & $2,150^{\mathrm{b}}$ & 103 & $<0.01$ \\
\hline \multicolumn{6}{|l|}{ Percentage } \\
\hline Protein & $3.19^{\mathrm{a}}$ & $3.33^{\mathrm{b}}$ & $3.44^{\mathrm{c}}$ & 0.07 & $<0.01$ \\
\hline Fat & $3.76^{\mathrm{c}}$ & $3.33^{\mathrm{b}}$ & $3.08^{\mathrm{a}}$ & 0.15 & $<0.01$ \\
\hline Lactose & $4.76^{\mathrm{a}}$ & $4.90^{\mathrm{b}}$ & $4.86^{\mathrm{b}}$ & 0.04 & $<0.01$ \\
\hline ECM yield, $\mathrm{kg} / \mathrm{d}$ & $40.4^{\mathrm{a}}$ & $42.7^{\mathrm{b}}$ & $42.1^{\mathrm{ab}}$ & 1.6 & 0.04 \\
\hline $\mathrm{NE}_{\mathrm{J}}$ balance & $-1.8^{\mathrm{a}}$ & $2.4^{\mathrm{b}}$ & $5.5^{\mathrm{c}}$ & 1.5 & $<0.01$ \\
\hline Milk energy $/ \mathrm{NE}_{\mathrm{L}}$ intake & $0.77^{\mathrm{a}}$ & $0.70^{\mathrm{b}}$ & $0.65^{\mathrm{b}}$ & 0.03 & $<0.01$ \\
\hline
\end{tabular}

${ }^{\mathrm{a}-\mathrm{c}}$ Means within a row with different superscripts are significantly different $(P \leq 0.05)$.

${ }^{1} \mathrm{BAS}=70 \%$ forage basal TMR; $\mathrm{CG}=$ basal TMR with $19 \%$ of the forages substituted for corn grain; GLYC = basal TMR with $19 \%$ of the forages substituted for refined glycerol from a soybean oil source plus protein supplements.

compared with CG $(P=0.05)$. Lactose content of milk increased by $0.14(P<0.01)$ and $0.10(P<0.01)$ percentage units for CG and GLYC diets, respectively.

Energy-corrected milk yield increased $2.4 \mathrm{~kg} / \mathrm{d}(P$ $=0.02$ ) between $\mathrm{CG}$ and BAS diets and tended to increase $1.7 \mathrm{~kg} / \mathrm{d}(P=0.07)$ between GLYC and BAS diets. The ECM yield did not differ between CG and GLYC $(P=0.46)$.

The $\mathrm{NE}_{\mathrm{L}}$ balance of cows on the BAS diet was negative, increased $4.2 \mathrm{Mcal} / \mathrm{d}(P<0.01)$ to a positive value when $\mathrm{CG}$ was fed, and increased $7.3 \mathrm{Mcal} / \mathrm{d}(P<$ $0.01)$ when GLYC was fed. The $\mathrm{NE}_{\mathrm{L}}$ balance was higher with GLYC than CG $(P=0.02)$. Efficiencies of dietary $\mathrm{NE}_{\mathrm{L}}$ output in milk were lower than BAS for both CG and GLYC diets $(P<0.03)$ and tended to be lower on GLYC versus CG $(P=0.06)$.

Mean milk fat globule diameter decreased by $6 \%$ $(P<0.01)$ between BAS and GLYC diets on a volume-weighted basis, and $7 \%(P=0.01)$ on a surface area-weighted basis (Table 3). Between BAS and CG diets, volume-weighted mean fat globule size tended to decrease $(P=0.10)$ and surface area-weighted mean diameter decreased significantly $(P=0.03)$. Mean fat globule size did not differ between CG and GLYC diets $(P>0.22)$. The smaller fat globule sizes on GLYC compared with BAS resulted in a greater membrane content per gram of milk fat, expressed either as specific area $\left(\mathrm{m}^{2} / \mathrm{g}\right.$ fat; $\left.P=0.01\right)$ or specific weight $(\mathrm{g} /$

Table 3. Milk fat globule sizes and membrane yields from cows $(\mathrm{n}=12)$ fed BAS, CG, and GLYC $\operatorname{diets}^{1}$ for $28 \mathrm{~d}$

\begin{tabular}{lccccc}
\hline & \multicolumn{3}{c}{ Treatment } & & \\
\cline { 2 - 3 } Item & BAS & CG & GLYC & SEM & P-value \\
\hline Mean diameter, $\mu \mathrm{m}$ & & & & \\
$\quad$ Volume weighted $\left(\mathrm{d}_{4,3}\right)^{2}$ & $3.98^{\mathrm{a}}$ & $3.83^{\mathrm{ab}}$ & $3.72^{\mathrm{b}}$ & 0.09 & 0.02 \\
$\quad$ Surface area weighted $\left(\mathrm{d}_{3,2}\right)^{2}$ & $3.43^{\mathrm{a}}$ & $3.26^{\mathrm{b}}$ & $3.22^{\mathrm{b}}$ & 0.11 & 0.03 \\
Specific area, $\mathrm{m}^{2} / \mathrm{g}$ of fat & $1.91^{\mathrm{a}}$ & $2.02^{\mathrm{ab}}$ & $2.06^{\mathrm{b}}$ & 0.07 & 0.03 \\
Membrane yield, g/d & 27.7 & 28.6 & 27.3 & 1.5 & 0.65 \\
Membrane content & $0.72^{\mathrm{b}}$ & $0.67^{\mathrm{ab}}$ & $0.62^{\mathrm{a}}$ & 0.03 & 0.02 \\
g/L of milk & $19.1^{\mathrm{a}}$ & $20.2^{\mathrm{ab}}$ & $20.6^{\mathrm{b}}$ & 0.7 & 0.03 \\
g/kg of fat & &
\end{tabular}

$\overline{\mathrm{a}, \mathrm{b}}$ Means within a row with different superscripts are significantly different $(P \leq 0.05)$.

${ }^{1} \mathrm{BAS}=70 \%$ forage basal TMR; $\mathrm{CG}=$ basal TMR with $19 \%$ of the forages substituted for corn grain; GLYC = basal TMR with $19 \%$ of the forages substituted for refined glycerol from a soybean oil source plus protein supplements.

${ }^{2} \mathrm{~d}_{4,3}=\Sigma \mathrm{N}_{\mathrm{i}} \mathrm{d}_{\mathrm{i}}^{4} / \Sigma \mathrm{N}_{\mathrm{i}} \mathrm{d}_{\mathrm{i}}^{3}$ and $\mathrm{d}_{3,2}=\Sigma \mathrm{N}_{\mathrm{i}} \mathrm{d}_{\mathrm{i}}^{3} / \Sigma \mathrm{N}_{\mathrm{i}} \mathrm{d}_{\mathrm{i}}^{2}$, where $\mathrm{N}_{\mathrm{i}}$ is the number of fat globules with diameter $\mathrm{d}_{\mathrm{i}}$. 
Table 4. Plasma concentrations of metabolites in lactating dairy cattle $(\mathrm{n}=12)$ fed BAS, CG, and GLYC $\operatorname{diets}^{1}$ for $28 \mathrm{~d}$

\begin{tabular}{|c|c|c|c|c|c|}
\hline \multirow[b]{2}{*}{ Item } & \multicolumn{3}{|c|}{ Treatment } & \multirow[b]{2}{*}{ SEM } & \multirow[b]{2}{*}{$P$-value } \\
\hline & BAS & CG & GLYC & & \\
\hline Glucose, $\mathrm{m} M$ & 3.11 & 3.21 & 3.19 & 0.09 & 0.77 \\
\hline Acetate, $\mathrm{m} M$ & $1.94^{\mathrm{a}}$ & $1.88^{\mathrm{a}}$ & $1.42^{\mathrm{b}}$ & 0.16 & 0.06 \\
\hline BHB, $m M$ & 1.16 & 0.91 & 0.90 & 0.10 & 0.15 \\
\hline Fatty acids, $\mu M$ & 83 & 87 & 56 & 13 & 0.17 \\
\hline Triacylglycerol, $\mu M$ & 93 & 99 & 76 & 9 & 0.20 \\
\hline
\end{tabular}

$\overline{\mathrm{a}, \mathrm{b}}$ Means within a row with different superscripts are significantly different $(P \leq 0.05)$.

${ }^{1} \mathrm{BAS}=70 \%$ forage basal TMR; $\mathrm{CG}=$ basal TMR with $19 \%$ of the forages substituted for corn grain; GLYC = basal TMR with $19 \%$ of the forages substituted for refined glycerol from a soybean oil source plus protein supplements.

$\mathrm{kg}$ fat; $P=0.01)$. Likewise, membrane content of milk fat tended to be higher on $\mathrm{CG}$ versus BAS $(P=0.06)$. However, daily milk fat globule membrane yield was reduced by GLYC because of the depression in milk fat yield.

\section{Plasma Metabolites}

Plasma glucose, BHB, NEFA, and TAG concentrations were not significantly affected by corn or glycerol addition to the BAS diet (Table 4). However, a trend

Table 5. Plasma concentrations of free amino acids $(\mu M)$ in lactating dairy cattle $(\mathrm{n}=12)$ fed BAS, CG, and GLYC $\operatorname{diets}^{1}$ for $28 \mathrm{~d}$

\begin{tabular}{|c|c|c|c|c|c|}
\hline \multirow[b]{2}{*}{$\mathrm{AA}$} & \multicolumn{3}{|c|}{ Treatment } & \multirow[b]{2}{*}{ SEM } & \multirow[b]{2}{*}{$P$-value } \\
\hline & BAS & CG & GLYC & & \\
\hline $\operatorname{Arg}$ & 77 & 78 & 70 & 5 & 0.47 \\
\hline His & 33 & 42 & 36 & 4 & 0.21 \\
\hline Ile & $119^{\mathrm{a}}$ & $115^{\mathrm{a}}$ & $90^{\mathrm{b}}$ & 8 & $<0.01$ \\
\hline Leu & $134^{\mathrm{a}}$ & $142^{\mathrm{a}}$ & $103^{\mathrm{b}}$ & 10 & $<0.01$ \\
\hline Lys & 80 & 84 & 70 & 6 & 0.23 \\
\hline Met & 24 & 24 & 24 & 2 & 0.97 \\
\hline Phe & 46 & 45 & 41 & 3 & 0.24 \\
\hline Thr & 130 & 127 & 131 & 10 & 0.95 \\
\hline Trp & 49 & 47 & 49 & 3 & 0.87 \\
\hline Val & $252^{\mathrm{a}}$ & $259^{\mathrm{a}}$ & $209^{\mathrm{b}}$ & 17 & 0.03 \\
\hline Ala & 267 & 259 & 232 & 16 & 0.23 \\
\hline Asn & 90 & 91 & 93 & 7 & 0.95 \\
\hline Asp & 9 & 11 & 9 & 1 & 0.11 \\
\hline Glu & 135 & 149 & 138 & 11 & 0.58 \\
\hline Gly & 288 & 335 & 307 & 18 & 0.18 \\
\hline Pro & 89 & 92 & 85 & 5 & 0.68 \\
\hline Ser & 93 & 95 & 95 & 5 & 0.94 \\
\hline Tyr & 58 & 58 & 60 & 5 & 0.92 \\
\hline $3-\mathrm{MeHis}^{2}$ & 7.4 & 6.9 & 7.6 & 1 & 0.95 \\
\hline $\mathrm{BCAA}^{3}$ & $505^{\mathrm{a}}$ & $517^{\mathrm{a}}$ & $401^{\mathrm{b}}$ & 33 & 0.01 \\
\hline Non-BC-EAA ${ }^{4}$ & 439 & 447 & 421 & 26 & 0.77 \\
\hline $\mathrm{EAA}^{5}$ & 944 & 964 & 822 & 58 & 0.15 \\
\hline NEAA $^{6}$ & 1,020 & 1,080 & 1,011 & 54 & 0.77 \\
\hline Total AA & 1,964 & 2,043 & 1,833 & 108 & 0.34 \\
\hline
\end{tabular}

$\overline{\mathrm{a}, \mathrm{b}}$ Means within a row with different superscripts are significantly different $(P \leq 0.05)$.

${ }^{1} \mathrm{BAS}=70 \%$ forage basal TMR; $\mathrm{CG}=$ basal TMR with $19 \%$ of the forages substituted for corn grain; GLYC = basal TMR with $19 \%$ of the forages substituted for refined glycerol from a soybean oil source plus protein supplements.

${ }^{2} 3$-MeHis $=3$-methylhistidine.

${ }^{3} \mathrm{BCAA}=$ branched-chain amino acids (Ile, Leu, and Val).

${ }^{4}$ Non-BC-EAA = nonbranched-chain EAA (Arg, His, Lys, Met, Phe, Thr, and Trp).

${ }^{5}$ BCAA and non-BC-EAA.

${ }^{6}$ Ala, Asn, Glu, Gly, Pro, Ser, and Tyr. 
Table 6. Total cell signaling protein abundances (normalized to $\beta$-actin) and their phosphorylation states (phosphorylated protein normalized to total) in mammary tissue of lactating cows $(\mathrm{n}=6)$ fed $\mathrm{BAS}, \mathrm{CG}$, and GLYC $\operatorname{diets}^{1}$ for $28 \mathrm{~d}^{2,3}$

\begin{tabular}{|c|c|c|c|c|c|}
\hline \multirow[b]{2}{*}{ Item } & \multicolumn{3}{|c|}{ Treatment } & \multirow[b]{2}{*}{ SEM } & \multirow[b]{2}{*}{$P$-value } \\
\hline & BAS & $\mathrm{CG}$ & GLYC & & \\
\hline \multicolumn{6}{|l|}{ S6K1 } \\
\hline Total & 1.17 & 1.28 & 1.21 & 0.12 & 0.31 \\
\hline Phosphorylation state & 0.39 & 0.35 & 0.41 & 0.07 & 0.64 \\
\hline \multicolumn{6}{|l|}{ 4EBP1 } \\
\hline Total & 1.10 & 1.15 & 1.00 & 0.17 & 0.15 \\
\hline Phosphorylation state & 0.32 & 0.47 & 0.31 & 1.00 & 0.46 \\
\hline \multicolumn{6}{|l|}{$\mathrm{eIF} 2 \mathrm{~B} \varepsilon$} \\
\hline Total & 0.55 & 0.63 & 0.57 & 1.00 & 0.69 \\
\hline Phosphorylation state & 1.38 & 1.18 & 1.22 & 0.24 & 0.48 \\
\hline \multicolumn{6}{|l|}{ PERK } \\
\hline Total & 0.66 & 0.78 & 0.75 & 0.10 & 0.26 \\
\hline Phosphorylation state & 0.38 & 0.37 & 0.34 & 0.05 & 0.55 \\
\hline \multicolumn{6}{|l|}{$\mathrm{eIF} 2 \alpha$} \\
\hline Total & 1.52 & 1.54 & 1.38 & 0.15 & 0.44 \\
\hline Phosphorylation state & $0.12^{\mathrm{a}}$ & $0.20^{\mathrm{ab}}$ & $0.23^{\mathrm{b}}$ & 0.05 & 0.12 \\
\hline \multicolumn{6}{|l|}{ Akt } \\
\hline Total & 0.78 & 0.77 & 0.78 & 0.08 & 0.95 \\
\hline Phosphorylation state & 0.88 & 0.90 & 0.94 & 0.20 & 0.86 \\
\hline \multicolumn{6}{|l|}{ AMPK } \\
\hline Total & $0.75^{\mathrm{a}}$ & $0.90^{\mathrm{b}}$ & $0.78^{\mathrm{ab}}$ & 0.07 & 0.06 \\
\hline Phosphorylation state & 0.67 & 0.35 & 0.48 & 0.19 & 0.39 \\
\hline
\end{tabular}

${ }^{\mathrm{a}, \mathrm{b}}$ Means within a row with different superscripts are significantly different $(P \leq 0.05)$.

${ }^{1} \mathrm{BAS}=70 \%$ forage basal TMR; $\mathrm{CG}=$ basal TMR with $19 \%$ of the forages substituted for corn grain; GLYC = basal TMR with $19 \%$ of the forages substituted for refined glycerol from a soybean oil source plus protein supplements.

${ }^{2}$ Representative blots in Figure 1.

${ }^{3} 4 \mathrm{EBP} 1=$ eukaryotic initiation factor $4 \mathrm{E}$ binding protein 1 ; Akt $=\mathrm{Ser} / \mathrm{Thr}$ protein kinase B; AMPK $=\mathrm{AMP}-$ activated protein kinase; eIF $2 \alpha=$ eukaryotic initiation factor 2 subunit $\alpha$; eIF2B $\varepsilon=$ eukaryotic initiation factor 2B subunit $\varepsilon$; PERK $=$ PKR-like endoplasmic reticulum kinase; S6K1 = ribosomal protein S6 kinase 1.

was found for a decrease in plasma acetate concentrations with GLYC compared with either BAS or CG $(P$ $=0.06)$.

Addition of corn to the BAS diet tended to increase His $(P=0.08)$ and Gly $(P=0.07)$ concentrations in plasma but had no effects on any other AA $(P>0.33)$. In contrast, the GLYC diet caused a decrease in each of the 3 branched-chain AA (BCAA: Ile, Leu, and Val) concentrations in plasma compared with either BAS or CG diets $(P \leq 0.03$; Table 5$)$. The remaining AA were not affected by GLYC $(P>0.10)$.

\section{Translational Response}

Addition of corn and glycerol to the BAS diet did not stimulate changes in phosphorylation status or abundance of proteins associated with mammary translation signaling pathways (Table 6). Total AMPK tended to be elevated with CG compared with BAS and GLYC $(P=0.06)$.

\section{DISCUSSION}

As the demand for biodiesel fuels increases, glycerol, as a co-product of biodiesel manufacture, will be in- creasingly available. Glycerol has been used as a feed additive in transition cow diets since the early 1950s to prevent the metabolic disorder of ketosis in dairy cattle (Johnson, 1954). An increased interest exists for glycerol as a routine ingredient in dairy cattle rations, and information on its feeding value is needed. Several studies have been conducted in which refined glycerol replaced a portion of the concentrate up to $15 \%$ of DMI (Khalili et al., 1997; Carvalho et al., 2011; Kass et al., 2012). Effects on milk yield and composition were not detected, indicating that glycerol is equivalent in value to the ingredients replaced. Statistical standards to declare a lack of effect are not as well established as those to declare a significant difference (e.g., $P<$ $0.05)$, so we chose to design an experiment that offered a greater opportunity to detect lactational effects of glycerol by adding it to increase the energy density of the diet (i.e., hypercalorically). Addition of $15 \%$ glycerol increased DMI and yields of milk, protein, and lactose and decreased milk fat yield. Addition of corn at a caloric equivalent to glycerol also increased DMI and yields of milk, protein, and lactose, but protein yield did not go up as high and fat yield did not decrease. 


\section{Milk Protein Stimulation}

Glycerol is a glucogenic substance similar to corn in that a portion is fermented in the rumen to propionate and a portion is converted to glucose postruminally (Rémond et al., 1993). Glycerol appears to exert a stronger effect on rumen VFA profile than grains though, because isocaloric substitution for corn or barley increases the rumen propionate concentration and decreases acetate (Khalili et al., 1997; Kass et al., 2012; Paiva et al., 2016). The tendency for a lower concentration of plasma acetate in GLYC cows versus those on BAS or CG may be related to such a ruminal effect. However, the net splanchnic release of acetate into circulation in lactating cows is highly positively related to rumen-fermentable OM intake (Loncke et al., 2015), which was higher on GLYC versus BAS, so acetate entry was not likely responsible for the $24 \%$ drop in plasma acetate concentration. Rather, the concentration drop may have been a consequence of diversion of plasma acetate into adipose lipids such as occurs during glucose infusion (Rigout et al., 2002). The change in $\mathrm{NE}_{\mathrm{L}}$ balance from a negative value on the BAS diet to a positive value on the GLYC diet and the tendency

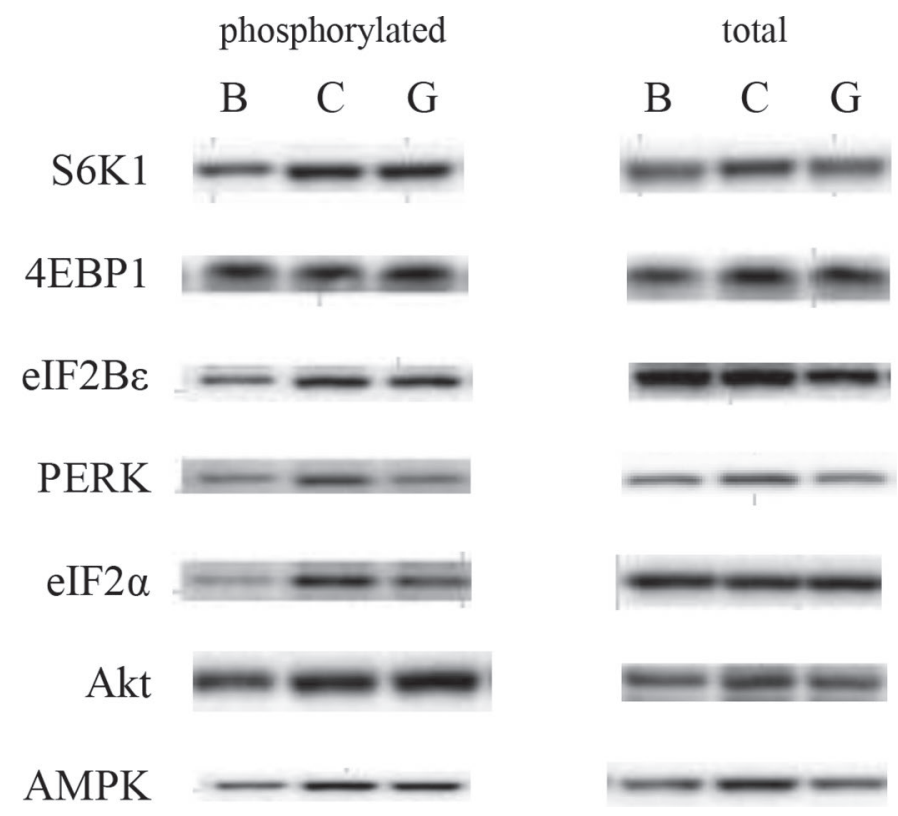

Figure 1. Representative Western blot images of phosphorylated and total forms of signaling proteins in mammary tissue of cows fed basal (B), corn grain (C), and glycerol (G) diets for 28 d (means from all cows presented in Table 6$)$. 4EBP1 = eukaryotic initiation factor $4 \mathrm{E}$ binding protein 1 ; Akt $=$ Ser $/ \mathrm{Thr}$ protein kinase B; $\mathrm{AMPK}=$ AMP-activated protein kinase; eIF $2 \alpha=$ eukaryotic initiation factor 2 subunit $\alpha$; eIF2B $\varepsilon=$ eukaryotic initiation factor $2 \mathrm{~B}$ subunit $\varepsilon$; PERK $=$ PKR-like endoplasmic reticulum kinase; $\mathrm{S} 6 \mathrm{~K} 1$ = ribosomal protein S6 kinase 1. for a more positive $\mathrm{NE}_{\mathrm{L}}$ balance on GLYC versus CG support this contention.

Total DMI was stimulated by addition of either glycerol or corn, and it tended to be higher with glycerol. Most studies have shown no effect on DMI when glycerol, refined or crude, is isocalorically and isonitrogenously substituted into diets (Khalili et al., 1997; DeFrain et al., 2004; Carvalho et al., 2011), although Kass et al. (2012) reported a $1.9 \mathrm{~kg} / \mathrm{d}$ increase in DMI with $15 \%$ glycerol replacing barley. Higher levels of substitution of crude glycerol have reduced DMI (Ezequiel et al., 2015; Paiva et al., 2016). Supplementation of $1,300 \mathrm{~g} / \mathrm{d}$ glycerol through the drinking water depressed intake of solid feed by transition cows but total $\mathrm{NE}_{\mathrm{L}}$ intake was not affected (Osborne et al., 2009). The stimulation of DMI by both CG and GLYC may be related to the decrease in NDF content of the diets compared with BAS because of a fill effect that is relieved under approximately 35\% dietary NDF (Dado and Allen, 1995).

When intakes of $\mathrm{NE}_{\mathrm{L}}$ and $\mathrm{MP}$ were depressed by glycerol, milk protein yield decreased in one experiment (Paiva et al., 2016) but remained unchanged in another (Ezequiel et al., 2015). When intakes of $\mathrm{NE}_{\mathrm{L}}$ and MP were elevated by glycerol, milk protein yield was not affected (Kass et al., 2012). Studies in which DMI was not affected by glycerol have shown no effect on milk protein yield (Khalili et al., 1997; Carvalho et al., 2011). Inconsistent reports of a milk protein effect may be related to an inability to detect small changes that occur with isocaloric replacement studies.

Increasing glucogenic energy supply through concentrate feeding or postruminal carbohydrate infusion stimulates milk protein production (Broster et al., 1978; Macleod et al., 1983; Rulquin et al., 2004; Rius et al., 2010; Toerien et al., 2010). Accordingly, the increase in milk protein yield caused by GLYC may be related to its glucogenicity, although it may also have been a consequence of the higher $\mathrm{CP}$ intake due to the stimulation of DMI and the unexpectedly higher CP percentage of the GLYC diet. However, none of the essential amino acid concentrations in plasma were increased by glycerol addition to the BAS diet and, in fact, concentrations of each of the BCAA were decreased in plasma. A drop in BCAA concentrations is typical of a postruminal glucose or euglycemic insulin effect. During prolonged insulin infusion into lactating cows or goats, plasma concentrations of essential amino acids decrease dramatically and the BCAA are reduced the most (Laarveld et al., 1981; Tesseraud et al., 1992; Mackle et al., 2000). Likewise, postruminal glucose infusion induces a decrease in plasma BCAA concentrations (Clark et al., 1977; Whitelaw et al., 1986; Curtis et al., 2014; Nichols et al., 2016), as do glucogenic substrates 
(Raggio et al., 2006). The reduction of plasma BCAA concentrations in the cows that were fed GLYC, but not those fed CG, suggests that glycerol elicits more of a glucose-insulin response than corn grain. The tendency for a stimulation of DMI with GLYC versus CG, resulting in cows on the GLYC diet consuming more glucogenic energy than cows on the CG diet, may have contributed to the larger glucose-insulin response. The higher glucogenicity may be responsible for the greater stimulation of milk protein yield by GLYC compared with CG.

We hypothesized that the milk protein stimulation from glucose or glucogenic feedstuffs is mediated by mTORC1 or integrated stress response (ISR) pathways in the mammary glands. However, the only change in phosphorylation state of key mTORC1 and ISR participants was an increase in peIF $2 \alpha$, which is inhibitory to protein synthesis. Stimulation of protein synthesis in muscle and liver of growing animals in the postprandial period following consumption of a meal is due to activation of intracellular mTORC1 by insulin and amino acids (Kimball et al., 2000; O'Connor et al., 2003, 2004). Upon activation, mTORC1 phosphorylates 4EBP1 and S6K1 to accelerate initiation of global mRNA translation (Wullschleger et al., 2006). Initiation of translation is also regulated by kinases of the ISR that phosphorylate eIF $2 \alpha$ and thereby inhibit ribosome recruitment in response to amino acid insufficiency, unfolded protein accumulation in the ER, and other stressors (Proud, 2005). In mammary cells in vitro, stimulators of protein synthesis such as insulin, IGF-1, glucose, and amino acids increase the phosphorylation state of mTORC1 targets and decrease phosphorylation of ISR targets within minutes (Moshel et al., 2006; Burgos et al., 2010; Appuhamy et al., 2011; Burgos et al., 2013). Within $2 \mathrm{~d}$ of commencing postruminal infusions of carbohydrate or amino acids into cows, phosphorylation states of mammary mTORC1 and ISR targets also change in accord with the increases in milk protein yield that occur (Rius et al., 2010; Toerien et al., 2010). However, abomasal infusions of amino acid mixtures lacking single essential amino acids had no effect on phosphorylation state of eIF $2 \alpha$ in mammary tissue collected after $5 \mathrm{~d}$ of infusion, and S6K1 phosphorylation and eIF2B $\varepsilon$ abundance both increased with no change in milk protein yield (Doelman et al., 2015a,b). These responses suggest that factors other than mTORC1 and ISR signaling may be responsible for long-term control of milk protein synthesis. Likewise, the current finding of no change in phosphorylation state of key participants in mTORC1- and ISR-mediated regulation of mRNA translation after $28 \mathrm{~d}$ of feeding milk protein-stimulating diets indicates that alternative hypotheses for the yield increases must be sought.

\section{Milk Fat Depression}

The observed decrease in milk fat yield and percentage from cows fed the GLYC diet in comparison to both BAS and CG diets lies in accordance with a previous study that reported a decrease in milk fat percentage due to isocaloric glycerol at an intake of $2.7 \mathrm{~kg} / \mathrm{d}$ (Vallance and McClymont, 1959). Although most studies in which glycerol replaces grain have not found a milk fat depression (Khalili et al., 1997; DeFrain et al., 2004; Carvalho et al., 2011), our study differs in that glycerol was added hypercalorically. Increasing the concentrate portion of a cow's diet so that $\mathrm{NE}_{\mathrm{L}}$ intake increases causes a decrease in milk fat yield, concentration, or both (Balch et al., 1955; Sutton, 1989), in part through CLA formation in the rumen (Bauman et al., 2008) and a CLA-mediated decrease in mammary expression of genes associated with lipogenesis (Harvatine and Bauman, 2006). A drop in milk fat yield also occurs in cows infused postruminally with glucose or glucose precursors (Lemosquet et al., 1997; Rigout et al., 2003; Nichols et al., 2016), which appears to be a consequence of insulin-mediated inhibition of mammary lipoprotein lipase activity (Mackle et al., 2000; Cant et al., 2002). The decrease in plasma acetate concentration we observed could also contribute to a glycerol-induced milk fat depression because the effects of CLA, propionate, and acetate on milk fat production are additive (Maxin et al., 2011).

Average milk fat globule size decreased significantly on GLYC compared with BAS. The membrane that surrounds lipid droplets in milk is a rich source of sphingolipids that possess anticancer properties, are anti-inflammatory, and help stimulate development of the central nervous system (Mills et al., 2011). Proteins in the milk fat globule membrane also confer protection against cancer and bacterial infection (Spitsberg, 2005 ). Factors that regulate globule membrane content of milk as it is expressed from the cow's udder have been studied very little. Globule size is positively correlated with daily milk fat yield (Wiking et al., 2004). For example, including unsaturated fat in the diet of cows or offering fresh pasture to cows decreases milk fat yield and also decreases average fat globule size (Avramis et al., 2003; Couvreur et al., 2007; Lopez et al., 2008). Increasing the proportion of a corn- and barley-based concentrate in the TMR of cows tended to decrease fat globule size (Argov-Argaman et al., 2014), even though milk fat yield was not depressed. The observation that cows in early lactation with high plasma insulin concentrations have higher ratios of phospholipid to TAG in their milk than low-insulin cows (Mesilati-Stahy et al., 2012) suggests that insulin reduces milk fat globule size. Although we did not detect an effect of CG on 
milk fat globule size, GLYC caused a significant decrease, again supporting the assertion that glycerol is more glucogenic than corn grain.

\section{CONCLUSIONS}

Addition of glycerol to a high-forage diet for lactating dairy cows exerted similar effects on milk composition as addition of corn grain, but the stimulation of milk protein yield and the depression of milk fat yield were greater with glycerol. Reductions in plasma acetate and BCAA concentrations on the GLYC diet, but not the CG diet, suggest that glycerol is more glucogenic than corn grain, which may have been responsible for the larger effects on milk component yields.

\section{ACKNOWLEDGMENTS}

The authors thank Laura Wright and staff at the Ponsonby Dairy Research Station (Ponsonby, ON, Canada) for their technical help and animal care during the experiment. The authors also acknowledge the financial support of Dairy Farmers of Canada (Mississauga, ON, Canada), NSERC Canada (Ottawa, ON, Canada), and the Ontario Ministry of Agriculture, Food and Rural Affairs (OMAFRA; Guelph, ON, Canada). R.V. Curtis was the recipient of an OMAFRA HQP Scholarship.

\section{REFERENCES}

Appuhamy, J. A. D. R. N., A. L. Bell, W. A. D. Nayananjalie, J. Escobar, and M. D. Hanigan. 2011. Essential amino acids regulate both initiation and elongation of mRNA translation independent of insulin in MAC-T cells and bovine mammary tissue slices. J. Nutr. 141:1209-1215.

Argov-Argaman, N., R. Mesilati-Stahy, Y. Magen, and U. Moallem. 2014. Elevated concentrate-to-forage ratio in dairy cow rations is associated with a shift in the diameter of milk fat globules and remodeling of their membranes. J. Dairy Sci. 97:6286-6295.

Avramis, C. A., H. Wang, B. W. McBride, T. C. Wright, and A. R. Hill. 2003. Physical and processing properties of milk, butter, and cheddar cheese from cows fed supplemental fish meal. J. Dairy Sci. 86:2568-2576.

Balch, C. C., S. Bartlett, Z. D. Hosking, V. W. Johnson, S. J. Rowland, and J. Turner. 1955. Studies of secretion of milk of low fat content by cows on diets low in hay and high in concentrates. V. The importance of the type of starch in the concentrates. J. Dairy Res. 22:10-15.

Bauman, D. E., J. W. Perfield, K. J. Harvatine, and L. H. Baumgard. 2008. Regulation of fat synthesis by conjugated linoleic acid: Lactation and the ruminant model. J. Nutr. 138:403-409.

Bequette, B. J., C. E. Kyle, L. A. Crompton, V. Buchan, and M. D. Hanigan. 2001. Insulin regulates milk production and mammary gland and hind-leg amino acid fluxes and blood flow. J. Dairy Sci. 84:241-255.

Boogers, I., W. Plugge, Y. Q. Stokkermans, and A. L. L. Duchateau. 2008. Ultra-performance liquid chromatographic analysis of amino acids in protein hydrolysates using an automated pre-column derivatisation method. J. Chromatogr. A 1189:406-409.
Broster, W. H., J. D. Sutton, and J. A. Bines. 1978. Concentrate:forage ratios for high-yielding dairy cows. Pages 325-352 in Recent Advances in Animal Nutrition. W. Haresign and D. Lewis, ed. Butterworths, London, UK.

Burgos, S. A., M. Dai, and J. P. Cant. 2010. Nutrient availability and lactogenic hormones regulate mammary protein synthesis through the mammalian target of rapamycin signaling pathway. J. Dairy Sci. 93:153-161.

Burgos, S. A., J. J. M. Kim, M. Dai, and J. P. Cant. 2013. Energy depletion of bovine mammary epithelial cells activates AMPK and suppresses protein synthesis through inhibition of mTORC1 signaling. Horm. Metab. Res. 45:183-189.

Cameron, M. R., T. H. Klusmeyer, G. L. Lynch, and J. H. Clark. 1991. Effects of urea and starch on rumen fermentation, nutrient passage to the duodenum, and performance of cows. J. Dairy Sci. 74:1321-1336.

Cant, J. P., D. R. Trout, F. Qiao, and N. G. Purdie. 2002. Milk synthetic response of the bovine mammary gland to an increase in the local concentration of arterial glucose. J. Dairy Sci. 85:494-503.

Carvalho, E. R., N. S. Schmelz-Roberts, H. M. White, P. H. Doane, and S. S. Donkin. 2011. Replacing corn with glycerol in diets for transition dairy cows. J. Dairy Sci. 94:908-916.

Chung, Y.-H., D. E. Rico, C. M. Martinez, T. W. Cassidy, V. Noirot, A. Ames, and G. A. Varga. 2007. Effects of feeding dry glycerin to early postpartum Holstein dairy cows on lactational performance and metabolic profiles. J. Dairy Sci. 90:5682-5691.

Clark, J. H., H. R. Spires, R. G. Derrig, and M. R. Bennink. 1977. Milk production, nitrogen utilization and glucose synthesis in lactating cows infused postruminally with sodium caseinate and glucose. J. Nutr. 107:631-644.

Cori, C. F., and W. M. Shine. 1935. The formation of carbohydrate from glycerophosphate in the liver of the rat. Science 82:134-135.

Couvreur, S., C. Hurtaud, P. G. Marnet, P. Faverdin, and J. L. Peyraud. 2007. Composition of milk fat from cows selected for milk fat globule size and offered either fresh pasture or a corn silage-based diet. J. Dairy Sci. 90:392-403.

Curtis, R. V., J. J. M. Kim, D. L. Bajramaj, J. Doelman, V. R. Osborne, and J. P. Cant. 2014. Decline in mammary translational capacity during intravenous glucose infusion into lactating dairy cows. J. Dairy Sci. 97:430-438.

Dado, R. G., and M. S. Allen. 1995. Intake limitations, feeding behavior, and rumen function of cows challenged with rumen fill from dietary fiber or inert bulk. J. Dairy Sci. 78:118-133.

DeFrain, J. M., A. R. Hippen, K. F. Kalscheur, and P. W. Jardon. 2004. Feeding glycerol to transition dairy cows: Effects on blood metabolites and lactation performance. J. Dairy Sci. 87:4195-4206.

Doelman, J., R. V. Curtis, M. Carson, J. J. M. Kim, J. A. Metcalf, and J. P. Cant. 2015a. Essential amino acid infusions stimulate mammary expression of eukaryotic initiation factor $2 \mathrm{~B} \varepsilon$ but milk protein yield is not increased during an imbalance. J. Dairy Sci. 98:4499-4508.

Doelman, J., J. J. M. Kim, M. Carson, J. A. Metcalf, and J. P. Cant. 2015b. Branched-chain amino acid and lysine deficiencies exert different effects on mammary translational regulation. J. Dairy Sci. 98:7846-7855.

Ezequiel, J. M. B., J. B. D. Sancarini, O. R. Machado Neto, Z. F. da Silva, M. T. C. Almeida, D. A. V. Silva, F. O. S. van Cleef, and E. H. C. B. van Cleef. 2015. Effects of high concentrations of dietary crude glycerin on dairy cow productivity and milk quality. J. Dairy Sci. 98:8009-8017.

Farr, V. C., K. Stelwagen, L. R. Cate, A. J. Molenaar, T. B. McFadden, and S. R. Davis. 1996. An improved method for the routine biopsy of bovine mammary tissue. J. Dairy Sci. 79:543-549.

Harvatine, K. J., and D. E. Bauman. 2006. SREBP1 and thyroid hormone responsive Spot 14 (S14) are involved in the regulation of bovine mammary lipid synthesis during diet-induced milk fat depression and treatment with CLA. J. Nutr. 136:2468-2474.

Hess, B. W., L. J. Krysl, M. V. Judkins, D. W. Holcombe, J. D. Hess, D. R. Hanks, and S. A. Huber. 1996. Supplemental cracked corn or wheat bran for steers grazing endophyte-free fescue pasture: 
Effects on live weight gain, nutrient quality, forage intake, particulate and fluid kinetics, ruminal fermentation, and digestion. J. Anim. Sci. 74:1116-1125.

Hurtaud, C., H. Rulquin, and R. Verite. 1998. Effect of graded duodenal infusions of glucose on yield and composition of milk from dairy cows. 1. Diets based on corn silage. J. Dairy Sci. 81:3239-3247.

Johnson, R. B. 1954. The treatment of ketosis with glycerol and propylene glycol. Cornell Vet. 44:6-21.

Kass, M., T. Ariko, T. Kaart, E. Rihma, M. Ots, D. Arney, and O. Kärt. 2012. Effect of replacement of barley meal with crude glycerol on lactation performance of primiparous dairy cows fed a grass silage-based diet. Livest. Sci. 150:240-247.

Khalili, H., T. Varvikko, V. Toivonen, K. Hissa, and M. Suvitie. 1997. The effects of added glycerol or unprotected free fatty acids or a combination of the two on silage intake, milk production, rumen fermentation and diet digestibility in cows given grass silage based diets. Agric. Food Sci. 6:349-362.

Kimball, S. R., L. S. Jefferson, H. V. Nguyen, A. Suryawan, J. A. Bush, and T. A. Davis. 2000. Feeding stimulates protein synthesis in muscle and liver of neonatal pigs through an mTOR-dependent process. Am. J. Physiol. Endocrinol. Metab. 279:E1080-E1087.

Klusmeyer, T. H., G. L. Lynch, J. H. Clark, and D. R. Nelson. 1991. Effects of calcium salts of fatty acids and proportion of forage in diet on ruminal fermentation and nutrient flow to duodenum of cows. J. Dairy Sci. 74:2220-2232.

Laarveld, B., D. A. Christensen, and R. P. Brockman. 1981. The effect of insulin on net metabolism of glucose and amino acids by the bovine mammary gland. Endocrinology 108:2217-2221.

Lemosquet, S., N. Rideau, H. Rulquin, P. Faverdin, J. Simon, and R. Vérité. 1997. Effect of a duodenal glucose infusion on the relationship between plasma concentrations of glucose and insulin in dairy cows. J. Dairy Sci. 80:2854-2865.

Loncke, C., P. Nozière, L. Bahloul, J. Vernet, H. Lapierre, D. Sauvant, and I. Ortigues-Marty. 2015. Empirical prediction of net splanchnic release of ketogenic nutrients, acetate, butyrate and $\beta$-hydroxybutyrate in ruminants: A meta-analysis. Animal 9:449463.

Loor, J. J., and J. H. Herbein. 1998. Exogenous conjugated linoleic acid isomers reduce bovine milk fat concentration and yield by inhibiting de novo fatty acid synthesis. J. Nutr. 128:2411-2419.

Lopez, C., V. Briard-Bion, O. Menard, F. Rousseau, P. Pradel, and J.-M. Besle. 2008. Phospholipid, sphingolipid, and fatty acid compositions of the milk fat globule membrane are modified by diet. J. Agric. Food Chem. 56:5226-5236.

Mackle, T. R., D. A. Dwyer, K. L. Ingvartsen, P. Y. Chouinard, D. A. Ross, and D. E. Bauman. 2000. Effects of insulin and postruminal supply of protein on use of amino acids by the mammary gland for milk protein synthesis. J. Dairy Sci. 83:93-105.

Macleod, G. K., D. G. Grieve, and I. McMillan. 1983. Performance of first lactation dairy cows fed complete rations of several ratios of forage to concentrate. J. Dairy Sci. 66:1668-1674.

Maxin, G., F. Glasser, C. Hurtaud, J. L. Peyraud, and H. Rulquin. 2011. Combined effects of trans-10,cis-12 conjugated linoleic acid, propionate, and acetate on milk fat yield and composition in dairy cows. J. Dairy Sci. 94:2051-2059.

Mesilati-Stahy, R., H. Malka, and N. Argov-Argaman. 2012. Association of plasma insulin concentration to fatty acid distribution between milk fat and membrane synthesis. J. Dairy Sci. 95:17671775 .

Mills, S., R. P. Ross, C. Hill, G. F. Fitzgerald, and C. Stanton. 2011. Milk intelligence: Mining milk for bioactive substances associated with human health. Int. Dairy J. 21:377-401.

Moshel, Y., R. E. Rhoads, and I. Barash. 2006. Role of amino acids in translational mechanisms governing milk protein synthesis in murine and ruminant mammary epithelial cells. J. Cell. Biochem. 98:685-700.

Nichols, K., J. J. M. Kim, M. Carson, J. A. Metcalf, J. P. Cant, and J. Doelman. 2016. Glucose supplementation stimulates peripheral branched-chain amino acid catabolism in lactating dairy cows during essential amino acid infusions. J. Dairy Sci. 99:1145-1160.

NRC. 2001. Nutrient Requirements of Dairy Cattle. 7th rev. ed. National Academies Press, Washington, DC.

O'Connor, P. M., S. R. Kimball, A. Suryawan, J. A. Bush, H. V. Nguyen, L. S. Jefferson, and T. A. Davis. 2003. Regulation of translation initiation by insulin and amino acids in skeletal muscle of neonatal pigs. Am. J. Physiol. Endocrinol. Metab. 285:E40-E53.

O'Connor, P. M., S. R. Kimball, A. Suryawan, J. A. Bush, H. V. Nguyen, L. S. Jefferson, and T. A. Davis. 2004. Regulation of neonatal liver protein synthesis by insulin and amino acids in pigs. Am. J. Physiol. Endocrinol. Metab. 286:E994-E1003.

Osborne, V. R., N. E. Odongo, K. C. Swanson, J. P. Cant, and B. W. McBride. 2009. Effects of supplementing glycerol and soybean oil in drinking water on feed and water intake, energy balance and production performance in periparturient dairy cows. J. Dairy Sci. 92:698-707.

Paiva, P. G., T. A. Del Valle, E. F. Jesus, V. P. Bettero, G. F. Almeida, I. C. S. Bueno, B. J. Bradford, and F. P. Rennó. 2016. Effects of crude glycerin on milk composition, nutrient digestibility and ruminal fermentation of dairy cows fed corn silage-based diets. Anim. Feed Sci. Technol. 212:136-142.

Proud, C. G. 2005. eIF2 and the control of cell physiology. Semin. Cell Dev. Biol. 16:3-12.

Raggio, G., S. Lemosquet, G. E. Lobley, H. Rulquin, and H. Lapierre. 2006. Effect of casein and propionate supply on mammary protein metabolism in lactating dairy cows. J. Dairy Sci. 89:4340-4351.

Rémond, B., E. Souday, and J. P. Jouany. 1993. In vitro and in vivo fermentation of glycerol by rumen microbes. Anim. Feed Sci. Technol. 41:121-132.

Rémond, D., J. I. Cabrera-Estrada, M. Champion, B. Chauveau, R. Coudure, and C. Poncet. 2004. Effect of corn particle size on site and extent of starch digestion in lactating cows. J. Dairy Sci. 87:1389-1399.

Rigout, S., C. Hurtaud, S. Lemosquet, A. Bach, and H. Rulquin. 2003. Lactational effect of propionic acid and duodenal glucose in cows. J. Dairy Sci. 86:243-253.

Rigout, S., S. Lemosquet, J. E. Van Eys, J. W. Blum, and H. Rulquin. 2002. Duodenal infusion of glucose decreases milk fat production in grass silage-fed dairy cows. J. Dairy Sci. 85:2541-2550.

Rius, A. G., J. A. D. R. N. Appuhamy, J. Cyriac, D. Kirovski, O. Becvar, J. Escobar, M. L. McGilliard, B. J. Bequette, R. M. Akers, and M. D. Hanigan. 2010. Regulation of protein synthesis in mammary glands of lactating dairy cows by starch and amino acids. J. Dairy Sci. 93:3114-3127.

Rode, L. M., D. C. Weakley, and L. D. Satter. 1985. Effect of forage amount and particle size in diets of lactating dairy cows on site of digestion and microbial protein synthesis. Can. J. Anim. Sci. 65:101-111.

Roesch, R. R., A. Rincon, and M. Corredig. 2004. Emulsifying properties of fractions prepared from commercial buttermilk by microfiltration. J. Dairy Sci. 87:4080-4087.

Rulquin, H., S. Rigout, S. Lemosquet, and A. Bach. 2004. Infusion of glucose directs circulating amino acids to the mammary gland in well-fed dairy cows. J. Dairy Sci. 87:340-349.

Spitsberg, V. L. 2005. Invited review: Bovine milk fat globule membrane as a potential nutraceutical. J. Dairy Sci. 88:2289-2294.

Sutton, J. D. 1989. Altering milk composition by feeding. J. Dairy Sci. $72: 2801-2814$.

Taylor, C. C., and M. S. Allen. 2005. Corn grain endosperm type and brown midrib 3 corn silage: Site of digestion and ruminal digestion kinetics in lactating cows. J. Dairy Sci. 88:1413-1424.

Tesseraud, S., J. Grizard, B. Makarski, E. Debras, G. Bayle, and C. Champredon. 1992. Effect of insulin in conjunction with glucose, amino acids and potassium on net metabolism of glucose and amino acids in the goat mammary gland. J. Dairy Res. 59:135-149.

Toerien, C. A., D. R. Trout, and J. P. Cant. 2010. Nutritional stimulation of milk protein yield of cows is associated with changes in 
phosphorylation of mammary eukaryotic initiation factor 2 and ribosomal S6 kinase 1. J. Nutr. 140:285-292.

Tyrrell, H. F., and J. T. Reid. 1965. Prediction of the energy value of cow's milk. J. Dairy Sci. 48:1215-1223.

Valadares, R. F. D., G. A. Broderick, S. C. Valadares Filho, and M. K. Clayton. 1999. Effect of replacing alfalfa silage with high moisture corn on ruminal protein synthesis estimated from excretion of total purine derivatives. J. Dairy Sci. 82:2686-2696.

Vallance, W. S., and G. L. McClymont. 1959. Depression in percentage of milk fat by parenteral glucose infusion and glycerol feeding. Nature 183:466-467.

Wang, C., Q. Liu, W. J. Huo, W. Z. Yang, K. H. Dong, Y. X. Huang, and G. Guo. 2009a. Effects of glycerol on rumen fermentation, urinary excretion of purine derivatives and feed digestibility in steers. Livest. Sci. 121:15-20.
Wang, C., Q. Liu, W. Z. Yang, W. J. Huo, K. H. Dong, Y. X. Huang, X. M. Yang, and D. C. He. 2009b. Effects of glycerol on lactation performance, energy balance and metabolites in early lactation dairy cows. Anim. Feed Sci. Technol. 151:12-20.

Whitelaw, F. G., J. S. Milne, E. R. Ørskov, and J. S. Smith. 1986. The nitrogen and energy metabolism of lactating cows given abomasal infusions of casein. Br. J. Nutr. 55:537-556.

Wiking, L., J. Stagsted, L. Björck, and J. H. Nielsen. 2004. Milk fat globule size is affected by fat production in dairy cows. Int. Dairy J. 14:909-913.

Wilbert, C. A., E. R. Prates, J. O. J. Barcellos, and J. Scafhäuser. 2013. Crude glycerin as an alternative energy feedstuff for dairy cows. Anim. Feed Sci. Technol. 183:116-123.

Wullschleger, S., R. Loewith, and M. N. Hall. 2006. TOR signalling in growth and metabolism. Cell 124:471-484. 